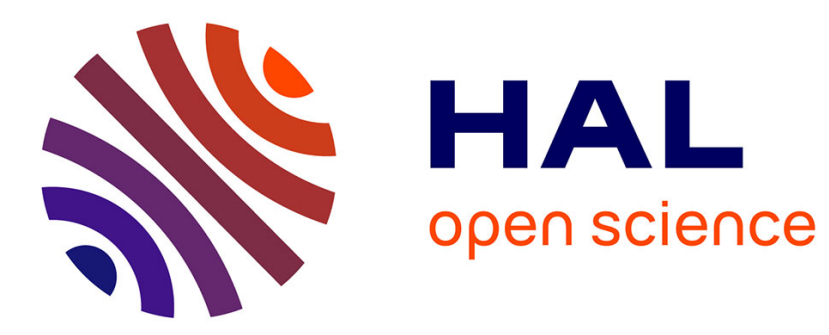

\title{
Asperger syndrome
}

Marc R. Woodbury-Smith, Fred R. Volkmar

\section{To cite this version:}

Marc R. Woodbury-Smith, Fred R. Volkmar. Asperger syndrome. European Child and Adolescent Psychiatry, 2008, 18 (1), pp.2-11. 10.1007/s00787-008-0701-0 . hal-00478064

\section{HAL Id: hal-00478064 https://hal.science/hal-00478064}

Submitted on 30 Apr 2010

HAL is a multi-disciplinary open access archive for the deposit and dissemination of scientific research documents, whether they are published or not. The documents may come from teaching and research institutions in France or abroad, or from public or private research centers.
L'archive ouverte pluridisciplinaire HAL, est destinée au dépôt et à la diffusion de documents scientifiques de niveau recherche, publiés ou non, émanant des établissements d'enseignement et de recherche français ou étrangers, des laboratoires publics ou privés. 


\author{
Marc R. Woodbury-Smith \\ Fred R. Volkmar
}

\section{Asperger syndrome}

Abstract Asperger syndrome (AS) is a chronic neurodevelopmental disorder of social interaction, communication, and a restricted range of behaviors or interests. Although not generally associated with intellectual disability, the severe social disability and, in many cases, associated mental health and other medical problems, result in disability throughout life. The diagnosis is often delayed, sometimes into adulthood, which is unfortunate because there are now a range of interventions available, and the current evidence supports intervention starting as early in childhood as possible. The aim of this review is to present a description of AS, an up to date synopsis of the literature pertaining to its etiology, co-morbidity and intervention options, and a discussion of current nosological controversies.

Key words Asperger syndrome - autism spectrum disorders

\author{
F.R. Volkmar \\ Yale Child Study Center \\ Yale University School of Medicine \\ 230 South Frontage Road \\ New Haven 06520, USA \\ M.R. Woodbury-Smith $(\square)$ \\ Developmental Psychiatry \\ Cambridge CB2 $2 \mathrm{AH}$, UK
Camglas House, $18 \mathrm{~b}$ Trump \\ E-Mail: marcwoodburysmith@doctors. \\ org.uk
}


(1) a mild form of autism, (2) a manifestation of autism in people of normal intellectual ability, (3) a higher verbally functioning form of autism, or (4) a 'socially motivated' form of autism. To complicate things, several different diagnostic criteria had been proposed. Its inclusion in ICD-10 and DSM-IV was intended to provide a set of criteria to overcome this problem. In the field trial conducted as part of DSM-IV and ICD-10 cases with clinical diagnoses of Asperger disorder were noted to differ BOTH from those with autism (e.g., in terms of verbal-performance IQ profile and increased rates of unusual circumscribed interests in AS cases) and those with pervasive developmental disorders not otherwise specified (PDD-NOS), with significantly greater severity of social difficulties in cases of AS [99]. Although offering the possibility of a single set of criteria that allow data across studies to be compared, the result has, unfortunately, been simply to change rather than solve the conceptual problems.

When AS was introduced in the ICD-10 and DSMIV it was placed alongside autism as a pervasive developmental disorder, sharing the same criteria with autism, but differing in terms of its apparently normal cognitive functioning and language development, the 'onset' rule, and on the basis of a number of communicative impairments that are present in autism but absent from AS. In addition, autism automatically takes priority in the diagnostic hierarchy (the 'precedence' rule). However, it has been argued that because of these onset and precedence 'rules', diagnosing AS becomes a near impossibility $[52,58]$, and the diagnosis is 'tilted' towards autism on the basis of vague developmental phenomena rather than on real empirical data concerning developmental pathways to social disability [109]. In addition, in view of the fact that they 'share' diagnostic criteria, the study of the differentiation of AS vis-à-vis autism has become problematic and tautological, and, therefore, it is no surprise that most research supports a relationship between them, and examination of external validity thus becomes meaningless.

It is important for the classification debate to move beyond the current arguments concerning the relationship between autism and AS, and instead examine the external validity of more sophisticated operationalised criteria. Several different models are possible, based on the absence or presence of early language impairments, or based on 'active but odd' versus 'socially aloof groupings for example. At the current time, the strongest evidence for external validity is when a definition closer to Asperger's description is used [46], as emphasized in the text revision of the DSM-IV, but, sadly, not incorporated into its diagnostic criteria.

Another related nosological uncertainty is the internal validity of AS. As discussed subsequently, both ICD-10 and DSM-IV have de-emphasized the communication impairment in favor of the social and behavioral features. This is unfortunate, as Asperger, Wing and others have argued that they are common and an essential feature. What is also unclear, however, is whether people with AS differ from one another because of differences in severity of symptoms, or whether there are 'subgroups' according to different phenotypic features, such as communication features, or pattern of ritualistic behaviors $[29,73,82$, 86]. The results have failed to reach any consensus. Whilst a number of studies have shown that people with AS differ according to a severity gradient [73, 86], others have shown evidence for subtypes [29, 82], which is also reflected in everyday clinical practice, where wide variation in symptomatology is seen. It is important to clarify this from both a nosological and genetic point of view.

\section{Clinical characteristics}

Most experts agree that impairment of reciprocal social interaction is the sine qua non of both AS and autism [95]. People with AS are typically motivated to interact with others, but find themselves socially isolated because of their odd communication style [45, $95,103]$, which is often overly formal and may take the form of an in-depth monologue about a topic of special interest regardless of whether their interlocutor is interested or not. As Asperger originally emphasized, these are children who 'talk before they walk' and 'words are their lifeline'-a stark contract to autism where speech is typically delayed and usually not a source of great strength. In AS speech is often verbose and tangential. There may also be peculiarities to the speech itself $[45,95,103]$. For example, it may lack the normal prosody and may also be odd in terms of volume, rate or rhythm. Sometimes pauses reflect the difficulties people with AS have in formulating answers to questions and structuring their discourse. As previously indicated, these pragmatic language impairments were unfortunately de-emphasized in the DSM-IV and ICD-10.

People with AS often engage in restricted and repetitive patterns of behavior [45, 95, 103]. Whilst these are categorized in both ICD-10 and DSM-IV as being of four different types, they can be usefully conceptualized as 'lower level' (including stereotyped motor movements) and 'higher level' (including rituals and circumscribed interests). Among people with AS, these behaviors are more likely to manifest as resistance to change in a personal routine or in their immediate environment, or with the pursuit of a circumscribed interest. Such interests are generally focussed on amassing large amounts of information 
on a particular topic, and typically, will take up a large amount of the individual's time, and take precedence over other activities. This intensity easily differentiates such interests from those of their peers. Importantly, such interests take precedence over social activities with peers, and 'interaction' with others may take the form of one-sided talk about their interest. What is also notable is that there is an increased engagement in such interests with age, and they can be debilitating in terms of frequency of engagement as well as degree of distress that they cause the person and their family [85].

A recent retrospective analysis of cases seen by Asperger indicated that of the 44 with detailed information, $82 \%$ clearly had special circumscribed interests [41]. The nature of the interest was mentioned for 33 cases, allowing categorization. A whole range of interests were represented, including animals and nature $(N=10)$, scientific interests $(N=9)$, and collecting facts $(N=8)$, and more rarely hobbies that could not be classified such as a fascination with puns, Mickey Mouse and national socialism.

\section{Diagnostic methods}

Currently, the gold standard diagnostic approach is to use clinical judgment combined with a combination of the autism diagnostic interview revised (ADI-R) [55] and autism diagnostic observation scale (ADOS) [54]. The ADI-R is a semi-structured interview with a primary caregiver, while the ADOS is a semi-structured play/interactive session. Both require specific training in administration. Both have algorithms for ICD-10 and DSM-IV diagnoses of autism, and also allow diagnosis of AS to be made based upon the precedence and onset rules discussed above. An alternative widely used semi-structured diagnostic instrument is the diagnostic interview for social and communication disorders (DISCO) [105]. A number of other instruments are available, specifically designed to be used where a diagnosis of AS is queried. These include screening instruments (ASQ [12], AQ [8], ASSQ [22]) and diagnostic instruments (ASDS [64], GADS [36], ASDI [35]). Most of these have data on validity and reliability and are commercially available. As with any standardized diagnostic tool, they do not replace good clinical judgment.

\section{Co-morbidities}

Most of the research on co-morbidities in PDDs has focussed on autism [31, 50, 111]. However, there is also consistent evidence that AS is associated with an increased prevalence of certain mental health problems [47, 103], in particular depression [34] and anxiety $[90,92]$, as well as certain medical problems, notably seizures and sleep problems [23], and other developmental disorders, namely Tourette's syndrome [7] and ADHD [34]. Unfortunately, many of these studies are based on psychiatric clinic samples, and diagnoses have been given according to clinical judgment rather than standardized measures, and further research in this area is needed. This notwithstanding, in the meantime it seems reasonable to conclude that co-morbidity is relatively common.

\section{Differential diagnosis: related concepts}

A number of other diagnostic labels have been used, and continue to be used, to describe people of normal intellectual ability who have difficulties with social interaction and communication. These include nonverbal learning disability from neuropsychology [75], schizoid personality from child psychotherapy [106, 107] and right hemisphere learning disability from child neurology [20, 101]. However, AS is the only term used in the current volumes of the DSM-IV and ICD-10.

What is unclear is whether these are fundamentally different syndromes or labels evolved from different areas of clinical expertise describing what is fundamentally the same syndrome. The term schizoid personality of childhood was coined by Wolff to describe a group of children whose clinical phenotype, whilst similar to Asperger's, was characterized by (1) prominent conduct disorder, (2) better adult adjustment, and (3) a slight increased risk of schizophrenia. In contrast nonverbal learning disabilities (NLD) ([75] and for recent review see [76]) is used to describe individuals with social and communicative difficulties who have a significant verbal/performance discrepancy favoring the former. Finally, the term developmental learning disabilities of the right hemisphere (DLDRH) [101] has been used to describe a cluster of symptoms that were associated with damage to the right side of the brain. Whilst there is little doubt that DLDRH is synonymous with NLD, and AS is synonymous with Wolff's cases, the relationship beyond this needs further clarification.

The relationship between AS and obsessive-compulsive symptoms (including obsessive-compulsive disorder (OCD) and, among adults, obsessive-compulsive personality disorder) is also not entirely clear, and the differential diagnosis can sometimes be difficult. In most instances of AS, however, the repetitive patterns of behavior, in particular the pursuit of circumscribed interests, are often associated with pleasure and mastery rather than egodystonicity. Even so, 
the similarities between these disorders may suggest a more fundamental relationship [11], which requires further exploration.

\section{Epidemiology}

Ehlers and Gillberg [21], using their own diagnostic criteria, found a point prevalence of 28.5/10,000 (95\% CI 0.6-56.5/10,000) for AS. Examining six other studies that ascertained the prevalence of AS alongside autism $[26,27]$ leads to a median prevalence estimate of 2.6/10,000. Of particular note is that these surveys consistently found the rates of AS to be lower than autism, with autism on average five times as common as AS (median prevalence for autism 13/10,000).

\section{Etiology}

\section{Genetic studies}

There is now compelling evidence from family and twin studies for a genetic basis for autism $([4,13,25$, 89]. The early work is summarized by Pericak-Vance [67]). Unfortunately, there is a paucity of studies specifically examining families of probands with AS. Asperger identified similar traits in family members of his patients, particularly among fathers, suggesting genetic factors were important. In addition, two studies have investigated genetic risk in relatives of AS probands. Volkmar and colleagues [96] presented data on 99 families of probands with AS, which demonstrated a strong family history of AS among first-degree relatives, and evidence of a genetic relationship between autism and AS. Ghaziuddin [30] came to similar conclusions.

For people with autism, the strongest support for linkage is on $2 \mathrm{q}[15,43,83]$ and $7 \mathrm{q}[16,43,84]$, particularly for people with phrase speech delay [14, $15,83]$, but with evidence of linkage also starting to coalesce in other chromosomal areas (see VeenstraVanderWeele et al. [94] for the most recent summary of linkage findings). Numerous genes have been investigated for possible candidacy, but there have been no consistently replicated findings.

Although these same genetic risk factors may be relevant for AS, there is a paucity of linkage and association studies specifically examining probands with AS. Indeed, at the time of writing only one study has investigated genetic linkage in AS [112], and two cytogenetic studies mapped breakpoints $[2,93]$. Ylisaukko-oja [112] examined 17 multiplex families with 119 affected probands, 72 of whom fulfilled the ICD-10 criteria for AS, and the remainder of whom had Asperger-like features but did not fulfill all diagnostic criteria. Linkage was observed at 1q21-22, 3p14-24 and 13q31-33. Interestingly, the loci on chromosomes 1 and 3 overlap with previously identified autism susceptibility loci, and on 1 and 13, with schizophrenia susceptibility loci. In contrast the two cytogenetic studies describe three different individuals with breakpoints involving the short arm of chromosome 17, at $17 \mathrm{p} 13$. Whilst strongly suggesting genes disrupted by this breakpoint may be responsible for the phenotype, candidate genes were not identified. Moreover, this chromosomal locus has not been previously identified by linkage strategies.

The male:female ratio of at least 9:1 for AS suggests that male specific genes might be involved in the phenotypic expression of this disorder. Stone and colleagues [88] examined patterns of linkage in 148 multiplex families obtained from the autism genetic resource exchange (AGRE), and found enhanced linkage for the male only group at $17 \mathrm{q}$, suggesting this susceptibility region may be important for the AS group. Moreover, samples stratified according to the presence of repetitive patterns of behavior also result in increased linkage to this region, particularly relevant in view of the prominence of such symptoms in the clinical phenotype of AS, whereby the presence of circumscribed interests is necessary for the diagnosis.

\section{Neuropsychological studies}

The neuropsychological literature on autism is vast, but broadly speaking falls into one of three areas: that pertaining to (1) theory of mind [5], (2) executive function [40] or (3) central coherence [37]. Briefly, individuals with AS relative to their age and IQ matched general population peers have been shown to have (1) difficulties 'passing' theory of mind tasks, (2) executive dysfunction and (3) a tendency to interpret visual stimuli in parts rather than wholes, so-called poor central coherence. These neuropsychological findings are similar to those observed among people with autism. Importantly, however, some studies have found that people with AS are relatively intact on theory of mind [113] and EF [72], providing some support, along with the findings on intellectual tests described below, for the external validity of AS vis-àvis autistic disorder.

In addition, other neuropsychological literature that has examined patterns of performance on tests of intellectual and more general abilities concluded that autism is characterized by a PIQ > VIQ profile, whilst AS, a VIQ > PIQ profile [53]. This latter pattern of strengths on verbal skills relative to visuospatial skills and non-verbal problem solving characterizes nonverbal learning disability, a term 
coined to describe individuals with socio-communicative impairments who have this particular pattern of cognitive strength and weakness. There is indeed strong support from neuropsychological studies for an association between AS and NLD [76]. Emphasis is placed on the right hemisphere as underlying the clinical and neuropsychological presentation of these two disorders, although, as will become apparent in the following section, a number of different neuroanatomical sites are implicated in autism and AS.

\section{Neuroimaging studies}

Several neuroanatomical regions of the brain have been implicated, including frontal lobe and temporal lobe regions, and the amygdala, but most studies have been probands with autism. Whilst a number of postmortem studies of people with autism implicated cerebellar abnormalities [9, 10, 18, 19], more recent research using MRI has failed to find any such abnormalities among people with autism, AS, and PDDNOS [80].

The studies which included people with AS demonstrated, along with their autism counterparts, abnormal patterns of 'activation' in the inferior temporal sulcus $[78,79]$, and areas of frontal dysactivation during the performance of neuropsychological tests $[24,38,62,74]$. Other studies of AS probands have also demonstrated abnormality of functional integration of the amygdala and parahippocampal gyrus [102], and structural abnormalities of the inferior temporal gyrus, entorhinal cortex and rostral fusiform gyrus [49].

A father and son both with AS and near identical areas of cortical dysmorphology have also been described [97]. In both, MRI scanning demonstrated a region of missing tissue in each hemisphere at the point at which the middle frontal gyrus intersects with the precentral sulcus. In another case report an 11year-old boy is described with a lesion in the right middle temporal gyrus white matter [98].

Megalencephaly remains a consistent finding among people with autism [51, 100], although no study has investigated brain size specifically among people with AS. However, interestingly, males are known to have larger brains than females, and there has been a suggestion that ASDs, and AS in particular, may be explained by an 'extreme male brain' phenotype [6].

\section{Management}

\section{Behavioral and educational interventions}

These are used to (1) develop social skills, (2) encourage adaptive problem solving strategies and reduce maladaptive patterns of behavior, and (3) teach more effective communication. Although not based on strong empirical evidence, their by and large ecologically valid approach and widespread use, with a handful of anecdotal single case reports, lends support to their effectiveness. In general the approach is based on using the child's strengths (typically verbal cognitive ability and nonsocial language skills) to address areas of weakness (nonverbal and social problem solving and pragmatic language). Although a detailed account of behavioral approaches is beyond the scope of the current review, certain themes dominate. These are summarized as follows:

Educational programs should be tailored according to each individual's pattern of cognitive strengths and vulnerabilities, as evidenced by their profile on neuropsychological tests:

Rote verbal learning of 'social rules' may be more effective than learning by role-playing or pictorially administered stimuli.

A 'parts to whole' approach should be used, where the verbal information is presented as a series of steps, rather than a narrative gestalt.

Most people with AS will cope better in small classes with the option for 1:1 supervision and support and small group activities.

As far as possible, children with AS should be integrated with their normotypical peers from whom they can generalize the social and communicative skills they learn during the more structured sessions. The curriculum may need to be adapted for the child with AS, in terms of, for example, allowing more time to complete tasks, making certain instructions have been understood, etc.

Adaptive skills should be taught explicitly by, for example, scheduling, practicing and rehearsing. Areas of vulnerability can be identified from scores on the Vineland adaptive behavior scale (VABS).

Organizational skills, often an area of vulnerability as a result of poor executive function, can be targeted by, for example, the use of scheduling, scripts, rules or lists ('things to do').

Social skills and pragmatic language training, usually delivered in the form of a group, refers to a variety of widely used approaches that include focussed instruction on actual target behaviors (such as, for example, eye contact), training in social perception, as provided by computer packages such as Let's Face It, or Mind Reading: An Interactive Guide to Human Emotions, and allowing the opportunity to practice the skills they have learned in varied, naturalistic contexts for generalization and maintenance (for a more detailed account see $[48,66])$. 


\section{Psychopharmacological interventions}

There are a number of symptoms that commonly occur among people with AS that may be responsive to particular pharmacologic interventions. In the absence of a strong base of evidence it seems reasonable to assume that people with AS will show a similar response as their general population counterparts. Nonetheless, people with AS may be more sensitive to the effects of psychotropics, and it is sensible to start with low doses, monitor change, and titrate slowly to the most effective dose.

Inattention/hyperactivity Hyperactivity and inattention are common in AS [34]. Psychostimulants, such as methylphenidate, and selective noradrenergic reuptake inhibitors, such as atomoxetine, are used to treat ADHD. In children and adolescents with autism, Asperger's syndrome or PDDNOS there is evidence for the efficacy of methylphenidate [70], although among people with PDDs there is a risk of higher rates of steretypies, tics, social withdrawal and stimulant-induced psychosis in conjunction with their use [77]. There is also some evidence to support the usefulness of atomoxetine for treating ADHD symptoms in children with autistic disorder [39].

Rigidity In the general population, certain selective serotonin reuptake inhibitors (SSRIs) have the strongest evidence of efficacy in the treatment of symptoms of repetitive thoughts and ritualistic patterns of behavior diagnosed as OCD. Although there are no clinical trials establishing the efficacy of these in treating such symptoms in people with AS, a few studies, specifically of children and adults with autism, have demonstrated efficacy for the SSRI Fluvoxamine [60] and the SSRI Fluoxetine [17], although Fluvoxamine resulted in serious side effects among children with autism [60], including hyperactivity and irritability, which was avoided in a subsequent study by employing a lower starting dose and less steep titration [56].

Irritability and aggression A number of treatment options have proven effective in the treatment of these symptoms in people with autism. These include the SSRIs Fluvoxamine [60] (but note caution discussed in previous section) and the SSRI Sertraline $[59,87]$, the novel serotonin and noradrenaline reuptake inhibitor (SNRI) Mirtazapine [68], and the atypical antipsychotic risperidine [69]. Of note, the studies of McDougle [59] and Posey [68] both included subsets with AS.

Depression A number of studies have demonstrated the high rates of depression among people with AS $[34,47,91,103]$. In the general population, several groups of drugs are used to treat depression, most notably the SSRIs. Although there are no clinical trials establishing the efficacy of antidepressants in people with AS, there is no reason to believe that these compounds would be less efficacious in AS than the general population. A few studies specifically of children and adults with autism have demonstrated efficacy for Fluoxetine [33], Citalopram [65], and Mirtazapine [68] (an SNRI). Of note, the study of Posey et al. also included subjects with AS and PDDNOS.

Anxiety Anxiety is also common among people with AS. In the general population, several groups of drugs are used to treat anxiety, most notably the SSRIs, Buspirone and $\beta$-blockers. Although there are no clinical trials establishing the efficacy of these in people with AS, there is no reason to believe that these compounds would be less efficacious in this group than the general population. A few studies specifically of children and adults with autism have demonstrated efficacy for Citalopram [65], Fluvoxamine [71], Sertraline [87] and Mirtazapine [68].

\section{Studies of outcome}

There is now some evidence that as many as $20 \%$ 'grow out' of their disorder, failing to meet the diagnostic criteria in adulthood [81], while many others 'improve' [81]. What is not clear is what factors predict those these differing outcomes. In contrast, other studies of outcome have investigated social adjustment, in terms of employment, opportunities and friendship. By far the most informative studies are longitudinal in design that measure outcome and its predictors and correlates, and there are now several studies that focus exclusively on people with autism with IQs in the normal range $[42,57]$, which indicate that although the majority improve over time, difficulties, in terms of communication skills, social adjustment and independent living, continue into adulthood.

A small body of literature also purports an association between AS and 'criminal offending' [63]. This 'evidence' is limited, however, as the majority of these are single case studies or case series, and do not, therefore, inform on the vast majority of people with AS who live in the community, who are probably no more likely to come into contact with the criminal justice system as perpetrators than their general population counterparts $[32,108]$.

\section{Future directions}

Although the relationship between autism and AS remains an important area of research, it will only be useful if current nosological conceptualizations are 
modified. Moving away from the assumption that Asperger's is simply a 'subtype' of autism may provide a better basis for external validity. The text revision of the DSM-IV has begun to recognize some of the more characteristic symptoms of AS, and recent research has started to investigate external validity based upon modified criteria [46]. Nosological research such as this is urgently needed, and will form the basis for emerging conceptualizations of AS, its underlying etiology, and its relationship to other disorders of social interaction, including autism, schizoid PD and NLD.

\section{References}

1. American Psychiatric Association (1994) Diagnostic and statistical manual of mental disorders, 4th edn. American Psychiatric Association, Washington, DC

2. Anneren G, Dahl N, Uddenfeldt U, Janols LO (1995) Asperger syndrome in a boy with a balanced de novo translocation: $\mathrm{t}(17 ; 19)(\mathrm{p} 13.3 ; \mathrm{p} 11)$ [letter]. Am J Med Genet 56:330-331

3. Asperger H (1944) Die "autistichen Psychopathen" im Kindersalter. Archive fur psychiatrie und Nervenkrankheiten 117:76-136

4. Bailey A, Le Couteur A, Gottesman I, Bolton P (1995) Autism as a strongly genetic disorder: evidence from a British twin study. Psychol Med 25:63-77

5. Baron-Cohen S (1995) Mindblindness. MIT Press, Cambridge

6. Baron-Cohen S, Hammer J (1997) Is autism an extreme form of the "male brain"? Adv Infancy Res 11:193-217

7. Baron-Cohen S, Scahill VL, Izaguirre J, Hornsey H, Robertson MM (1999) The prevalence of Gilles de la Tourette syndrome in children and adolescents with autism: a large scale study. Psychol Med 29:1151-1159

8. Baron-Cohen S, Wheelwright $S$, Skinner R, Martin J, Clubley E (2001) The autism-spectrum quotient (AQ): evidence from Asperger syndrome/ high-functioning autism, males and females, scientists and mathematicians. J Autism Dev Disord 31:5-17 (erratum appears in J Autism Dev Disord 2001 Dec;31(6):603)

9. Bauman M, Kemper TL (1985) Histoanatomic observations of the brain in early infantile autism. Neurology 35:866-874

10. Bauman ML (1996) Brief report: neuroanatomic observations of the brain in pervasive developmental disorders. J Autism Dev Disord 26:199-203

11. Bejerot S (2007) An autistic dimension: a proposed subtype of obsessive-compulsive disorder. Autism 11:101-110

12. Berument SK, Rutter M, Lord C, Pickles A, Bailey A (1999) Autism screening questionnaire: diagnostic validity. Br J Psychiatry 175:444-451
13. Bolton $\mathrm{P}$, Macdonald H, Pickles A, Rios P et al (1994) A case-control family history study of autism. J Child Psychol Psychiatry 35:877-900

14. Bradford Y, Haines J, Hutcheson $\mathrm{H}$, Gardiner M, Braun T, Sheffield V, Cassavant T, Huang W, Wang K, Vieland V, Folstein S, Santangelo S, Piven J (2001) Incorporating language phenotypes strengthens evidence of linkage to autism. Am J Med Genet 105:539-547

15. Buxbaum JD, Silverman JM, Smith CJ, Kilifarski M, Reichert J, Hollander E, Lawlor BA, Fitzgerald M, Greenberg DA, Davis KL (2001) Evidence for a susceptibility gene for autism on chromosome 2 and for genetic heterogeneity. Am J Hum Genet 68:15141520 (erratum appears in Am J Hum Genet 2001 Aug;69(2):470)

16. CLSA (1999) An autosomal genomic screen for autism. Am J Med Genet (Neuropsychiatr Genet) 88:609-615

17. Cook EH Jr, Rowlett R, Jaselskis C, Leventhal BL (1992) Fluoxetine treatment of children and adults with autistic disorder and mental retardation. J Am Acad Child Adolesc Psychiatry 31:739-745

18. Courchesne E, Townsend J, Saitoh O (1994) The brain in infantile autism: posterior fossa structures are abnormal. Neurology 44:214-223

19. Courchesne E, Yeung-Courchesne R, Press GA, Hesselink JR, Jernigan TL (1988) Hypoplasia of cerebellar vermal lobules VI and VII in autism. $\mathrm{N}$ Engl J Med 318:1349-1354

20. Denckla M (1983) The neuropsychology of social-emotional learning disabilities. Arch Neurol 40:461-462

21. Ehlers S, Gillberg C (1993) The epidemiology of Asperger syndrome. A total population study. J Child Psychol Psychiatry 34:1327-1350

22. Ehlers S, Gillberg C, Wing L (1999) A screening questionnaire for Asperger syndrome and other high-functioning autism spectrum disorders in school age children. J Autism Dev Disord 29:129-141
23. Filipek P (2005) Medical aspects of autism. In: Volkmar FR, Klin A, Paul R, Cohen DJ (eds) Handbook of autism and pervasive developmental disorders. Wiley, Hoboken, pp 534578

24. Fletcher PC, Happe F, Frith U, Baker SC, Dolan RJ, Frackowiak RS, Frith CD (1995) Other minds in the brain: a functional imaging study of "theory of mind" in story comprehension. Cognition 57:109-128

25. Folstein S, Rutter M (1977) Infantile autism: a genetic study of 21 twin pairs. J Child Psychol Psychiatry 18:297-321

26. Fombonne E (2005) Epidemiological studies of pervasive developmental disorders. In: Volkmar FR, Klin A, Paul R, Cohen DJ (eds) Handbook of autism and pervasive developmental disorders. Wiley, Hoboken, pp 42-69

27. Fombonne E, Tidmarsh L (2003) Epidemiologic data on Asperger disorder. Child Adolesc Psychiatr Clin N Am 12:15-21

28. Frith U (1991) Autism and Asperger's syndrome. Cambridge University Press, Cambridge

29. Ghaziuddin M (2008) Defining the behavioral phenotype of Asperger syndrome. J Autism Dev Disord 38:138-142

30. Ghaziuddin M (2005) A family history study of Asperger syndrome. J Autism Dev Disord 35:177-182

31. Ghaziuddin M, Ghaziuddin N, Greden J (2002) Depression in persons with autism: implications for research and clinical care. J Autism Dev Disord 32:299-306

32. Ghaziuddin M, Tsai L, Ghaziuddin N (1991) Brief report: violence in Asperger syndrome, a critique. J Autism Dev Disord 21:349-354

33. Ghaziuddin M, Tsai L, Ghaziuddin N (1991) Fluoxetine in autism with depression (letter; comment). J Am Acad Child Adolesc Psychiatry 30:508-509

34. Ghaziuddin M, Weidmer-Mikhail E, Ghaziuddin N (1998) Comorbidity of Asperger syndrome: a preliminary report. J Intellect Disabil Res 42:279283 
35. Gillberg C, Gillberg C, Rastam M, Wentz E (2001) The Asperger syndrome (and high-functioning autism) diagnostic interview (ASDI): a preliminary study of a new structured clinical interview. Autism 5:57-66

36. Gilliam J (2000) Gilliam Asperger's disorder scale. PRO-ED, Austin

37. Happe F (2005) The weak central coherence account of autism. In: Volkmar F, Paul R, Klin A, Donald C (eds) Handbook of autism and pervasive developmental disorders. Wiley, Hoboken, pp 640-649

38. Happe F, Ehlers S, Fletcher P, Frith U, Johansson M, Gillberg C, Dolan R, Frackowiak R, Frith C (1996) 'Theory of mind' in the brain. Evidence from a PET scan study of Asperger syndrome. Neuroreport 8:197-201

39. Hazell P (2007) Drug therapy for attention-deficit/hyperactivity disorder-like symptoms in autistic disorder. J Paediatr Child Health 43:19-24

40. Hill EL (2004) Evaluating the theory of executive dysfunction in autism. Dev Rev 24:189-233

41. Hippler K, Klicpera C (2003) A retrospective analysis of the clinical case records of 'autistic psychopaths' diagnosed by Hans Asperger and his team at the University Children's Hospital, Vienna. Philos Trans R Soc Lond B Biol Sci 358:291-301

42. Howlin P (2000) Outcome in adult life for more able individuals with autism or Asperger syndrome. Autism 4:6383

43. International Molecular Genetic Study of Autism Consortium (2001) A genomewide screen for autism: strong evidence for linkage to chromosomes $2 \mathrm{q}, 7 \mathrm{q}$, and 16p. Am J Hum Genet 69:570-581

44. Kanner L (1943) Autistic disturbances of affective contact. Nerv Child 2:217250

45. Klin A, McPartland J, Volkmar FR (2005) Asperger syndrome. In: Volkmar FR, Klin A, Paul R, Cohen DJ (eds) Handbook of autism and pervasive developmental disorders. Wiley, Hoboken, pp 88-125

46. Klin A, Pauls D, Schultz R, Volkmar F (2005) Three diagnostic approaches to Asperger syndrome: implications for research. J Autism Dev Disord 35:221-234

47. Klin A, Volkmar FR (1997) Asperger's syndrome. In: Cohen DJ, Volkmar FR (eds) Handbook of autism \& pervasive developmental disorders. Wiley, New York, pp 94-122
48. Klin A, Volkmar FR (2000) Treatment and intervention guidelines for individuals with Asperger syndrome. In: Klin A, Volkmar FR (eds) Asperger syndrome. The Guilford Press, New York, pp 340-366

49. Kwon H, Ow A, Pedatella K, Lotspeich L, Reiss A (2004) Voxel-based morphometry elucidates structural neuroanatomy of high-functioning autism and Asperger syndrome. Dev Med Child Neurol 46:760-764

50. Lainhart JE (1999) Psychiatric problems in individulas with autism, their parents and siblings. Int Rev Psychiatry 11:278-298

51. Lainhart JE, Piven J, Wzorek M, Landa R, Santangelo SL, Coon H, Folstein SE (1997) Macrocephaly in children and adults with autism. J Am Acad Child Adolesc Psychiatry 36:282-290

52. Leekam S, Libby S, Wing L, Gould J, Gillberg C (2000) Comparison of ICD10 and Gillberg's criteria for Asperger syndrome. Autism 4:11-28

53. Lincoln A, Courchesne E, Allen M, Hanson E, Ene M (1998) Neurobiology of Asperger syndrome: seven case studies and quantitative magnetic resonance imaging findings. In: Schopler E, Mesibov GB, Kunc LJ (eds) Asperger syndrome or high functioning autism? Plenum, New York, pp 145-166

54. Lord C, Risi S, Lambrecht L, Cook EH, Leventhal BL, DiLavore PC, Pickles A, Rutter M (2000) The autism diagnostic observation schedule-generic: a standard measure of social and communication deficits associated with the spectrum of autism. J Autism Dev Disord 30:205-223

55. Lord C, Rutter M, Le Couteur A (1994) Autism diagnostic interview-revised: a revised version of a diagnostic interview for caregivers of individuals with possible pervasive developmental disorders. J Autism Dev Disord 24:659-685

56. Martin A, Koenig K, Anderson GM, Scahill L (2003) Low-dose fluvoxamine treatment of children and adolescents with pervasive developmental disorders: a prospective, openlabel study. J Autism Dev Disord 33:77-85

57. Mawhood L, Howlin P, Rutter M (2000) Autism and developmental receptive language disorder-a comparative follow-up in early adult life. I: Cognitive and language outcomes. J Child Psychol Psychiatry 41:547-559

58. Mayes SD, Calhoun SL, Crites DL (2001) Does DSM-IV Asperger's disorder exist? J Abnorm Child Psychol 29:263-271
59. McDougle CJ, Brodkin ES, Naylor ST, Carlson DC, Cohen DJ, Price LH (1998) Sertraline in adults with pervasive developmental disorders: A prospective open-label investigation. J Clin Psychopharmacol 18:62-66

60. McDougle CJ, Naylor ST, Cohen DJ, Volkmar FR, Heninger GR, Price LH (1996) A double-blind, placebo-controlled study of fluvoxamine in adults with autistic disorder (see comments). Arch Gen Psychiatry 53:10011008

61. Miller JN, Ozonoff S (2000) The external validity of Asperger disorder: lack of evidence from the domain of neuropsychology. J Abnorm Psychol 109:227-238

62. Mundy P (2003) The neural basis of social impairments in autism: the role of the dorsal medial-frontal cortex and anterior cingulate system. J Child Psychol Psychiatry 44:793-809

63. Murphy D (2002) Asperger's Syndrome: forensic considerations. Forensic Update 68:10-16

64. Myles BS (2001) Asperger syndrome diagnostic scale. PRO-ED, Austin

65. Namerow LB, Thomas P, Bostic JQ, Prince J, Monuteaux MC (2003) Use of citalopram in pervasive developmental disorders. J Dev Behav Pediatr 24:104-108

66. Paul R (2003) Promoting social communication in high functioning individuals with autistic spectrum disorders. Child Adoles Psychiatr Clin N Am 12:87-106 (vi-vii)

67. Pericak-Vance MA (2003) The genetics of autistic disorder. In: Plomin R, DeFries JC et al (eds) Behavioral genetics in the postgenomic era. American Psychological Association, Washington, DC, pp 267-288

68. Posey DJ, Guenin KD, Kohn AE, Swiezy NB, McDougle CJ (2001) A naturalistic open-label study of mirtazapine in autistic and other pervasive developmental disorders. J Child Adolesc Psychopharmacol 11:267-277

69. Research Units on Pediatric Psychopharmacology Autism Network (2002) Risperidine in children with autism and serious behavioral problems. N Eng J Med 347:314-321

70. Research Units on Pediatric Psychopharmacology Autism Network (2005) Randomized, controlled, crossover trial of methylphenidate in pervasive developmental disorders with hyperactivity. Arch Gen Psychiatry 62:1266-1274

71. Riddle MA, Bernstein GA, Cook EH, Leonard HL, March JS, Swanson JM (1999) Anxiolytics, adrenergic agents, and naltrexone. J Am Acad Child Adolesc Psychiatry 38:546-556 
72. Rinehart NJ, Bradshaw JL, Tonge BJ, Brereton AV, Bellgrove MA (2002) A neurobehavioral examination of individuals with high-functioning autism and Asperger disorder using a frontostriatal model of dysfunction. Behav Cogn Neurosci Rev 1:164-177

73. Ring H, Woodbury-Smith M, Watson $\mathrm{P}$, Wheelwright $\mathrm{S}$, Baron-Cohen $\mathrm{S}$ (2008) Clinical heterogeneity among people with high functioning autism spectrum conditions evidence favouring a continuous severity gradient. Behav Brain Funct 4:11

74. Ring HA, Baron-Cohen S, Wheelwright S, Williams SC, Brammer M, Andrew C, Bullmore ET (1999) Cerebral correlates of preserved cognitive skills in autism: a MRI study of embedded figures task performance. Brain 122:1305-1315

75. Rourke BP (1987) Syndrome of nonverbal learning disabilities: the final common pathway of white-matter disease/dysfunction? Clin Neuropsychol 1:209-234

76. Rourke BP, Tsatsanis KD (2000) Nonverbal learning disabilities and Asperger syndrome. In: Klin A, Volkmar FR (eds) Asperger syndrome. The Guilford Press, New York, pp 231-253

77. Scahill L, Martin A (2005) Psychopharmacology. In: Volkmar F, Paul R, Klin A, Donald C (eds) Handbook of autism and pervasive developmental disorders. Wiley, Hoboken, pp 11021120

78. Schultz RT, Gauthier I, Klin A, Fulbright RK, Anderson AW, Volkmar F, Skudlarski P, Lacadie C, Cohen DJ, Gore JC (2000) Abnormal ventral temporal cortical activity during face discrimination among individuals with autism and Asperger syndrome. Arch Gen Psychiatry 57:331-340

79. Schultz RT, Grelotti DJ, Klin A, Kleinman J, Van der Gaag C, Marois R, Skudlarski P (2003) The role of the fusiform face area in social cognition: implications for the pathobiology of autism. Philos Trans R Soc Lond Ser B Biol Sci 358:415-427

80. Schultz RT, Romanski LM, Tsatsanis KD (2000) Neurofunctional models of autistic disorder and Asperger syndrome: clues from neuroimaging. In: Klin A, Volkmar FR (eds) Asperger syndrome. The Guilford Press, New York, pp 172-209

81. Seltzer MM, Krauss MW, Shattuck PT, Orsmond G, Swe A, Lord C (2003) The symptoms of autism spectrum disorders in adolescence and adulthood. J Autism Dev Disord 33:565581
82. Shao Y, Cuccaro ML, Hauser ER, Raiford KL, Menold MM, Wolpert CM, Ravan SA, Elston L, Decena K, Donnelly SL, Abramson RK, Wright HH, DeLong GR, Gilbert JR, PericakVance MA (2003) Fine mapping of autistic disorder to chromosome 15 q11-q13 by use of phenotypic subtypes. Am J Hum Genet 72:539-548

83. Shao Y, Raiford KL, Wolpert CM, Cope HA, Ravan SA, Ashley-Koch AA, Abramson RK, Wright HH, DeLong RG, Gilbert JR, Cuccaro ML, PericakVance MA (2002) Phenotypic homogeneity provides increased support for linkage on chromosome 2 in autistic disorder. Am J Hum Genet 70:1058-1061

84. Shao Y, Wolpert CM, Raiford KL, Menold MM, Donnelly SL, Ravan SA, Bass MP, McClain C, von Wendt L, Vance JM, Abramson RH, Wright HH, Ashley-Koch A, Gilbert JR, DeLong RG, Cuccaro ML, Pericak-Vance MA (2002) Genomic screen and follow-up analysis for autistic disorder. Am J Med Genet 114:99-105

85. South M, Ozonoff S, McMahon W (2005) Repetitive behavior profiles in apserger syndrome adn high-functioning autism. J Autism Dev Disord 35:145-158

86. Spiker D, Lotspeich LJ, Dimiceli S, Myers RM, Risch N (2002) Behavioral phenotypic variation in autism multiplex families: evidence for a continuous severity gradient. Am J Med Genet 114:129-136

87. Steingard RJ, Zimnitzky B, DeMaso DR, Bauman ML, Bucci JP (1997) Sertraline treatment of transitionassociated anxiety and agitation in children with autistic disorder. J Child Adolesc Psychopharmacol 7:9-15

88. Stone J, Merriman B, Cantor RY, Gilliam T, Geshwind D, Nelson S (2004) Evidence for sex specific risk alleles in autism spectrum disorder. Am J Hum Genet 75:1117-1123

89. Szatmari P, MacLean JE, Jones MB, Bryson SE, Zwaigenbaum L, Bartolucci G, Mahoney WJ, Tuff L (2000) The familial aggregation of the lesser variant in biological and nonbiological relatives of PDD probands: a family history study. J Child Psychol Psychiatry 41:579-586

90. Tantam D (2000) Adolescence and adulthood of individuals with Asperger syndrome. In: Klin A, Volkmar FR (eds) Asperger syndrome. The Guilford Press, New York, pp 367-399

91. Tantam D (1991) Asperger syndrome in adulthood. In: Frith U (eds) Autism and Asperger syndrome. Cambridge University Press, Cambridge
92. Tantam D (2000) Psychological disorder in adolescents and adults with Asperger syndrome. Autism 4:47-62

93. Tentler $\mathrm{D}$, Johannesson $\mathrm{T}$, Johansson M, Rastam M, Gillberg C, Orsmark C, Carlsson B, Wahlstrom J, Dahl N (2003) A candidate region for Asperger syndrome defined by two $17 \mathrm{p}$ breakpoints. Eur J Hum Genet 11:189-195

94. Veenstra-VanderWeele J, Cook EH Jr (2004) Molecular genetics of autism spectrum disorder. Mol Psychiatry 9:819-832

95. Volkmar FR, Klin A (2000) Diagnostic issues in Asperger syndrome. In: Klin A, Volkmar FR (eds) Asperger syndrome. The Guilford Press, New York, pp 25-71

96. Volkmar FR, Klin A, Pauls D (1998) Nosological and genetic aspects of Asperger syndrome. J Autism Dev Disord 28:457-463

97. Volkmar FR, Klin A, Schultz R, Bronen R, Marans WD, Sparrow S, Cohen DJ (1996) Asperger's syndrome (clinical conference). J Am Acad Child Adolesc Psychiatry 35:118-123

98. Volkmar FR, Klin A, Schultz RT, Rubin E, Bronen R (2000) Asperger's disorder. Am J Psychiatry 157:262267

99. Volkmar FR, Klin A, Siegel B, Szatmari P, Lord C, Campbell M, Freeman BJ, Cicchetti DV, Rutter M, Kline W et al (1994) Field trial for autistic disorder in DSM-IV. Am J Psychiatry 151:1361-1367

100. Wallace GL, Treffert DA (2004) Head size and autism. Lancet 363:10031004

101. Weintraub S, Mesulam MM (1983) Developmental learning disabilities of the right hemisphere. Emotional, interpersonal, and cognitive components. Arch Neurol 11:463-468

102. Welchew DE, Ashwin C, Berkouk K, Salvador R, Suckling J, Baron-Cohen S, Bullmore E (2005) Functional disconnectivity of the medial temporal lobe in Asperger's syndrome. Biol Psychiatry 57:991-998

103. Wing L (1981) Asperger's syndrome: a clinical account. Psychol Med 11:115-129

104. Wing L (1997) The autistic spectrum. Pergamon, New York

105. Wing L, Leekam SR, Libby SJ, Gould J, Larcombe M (2002) The diagnostic interview for social and communication disorders: background, interrater reliability and clinical use. $J$ Child Psychol Psychiatry 43:307-325

106. Wolff S (1991) "Schizoid" personality in childhood and adult life. I: The vagaries of diagnostic labelling. $\mathrm{Br} \mathrm{J}$ Psychiatry 159:615-620 
107. Wolff S, Barlow A (1979) Schizoid personality in childhood: a comparative study of schizoid, autistic and normal children. J Child Psychol Psychiatry 20:29-46

108. Woodbury-Smith M, Clare IC, Holland A, Kearns A (2006) High functioning autistic spectrum disorders, offending and other law-breaking: findings from a community sample. J Forensic Psychiatry Psychol 17:108120
109. Woodbury-Smith M, Klin A, Volkmar F (2005) Asperger's syndrome: a comparison of clinical diagnoses and those made according to the ICD-10 and DSM-IV. J Autism Dev Disord 35:235-240

110. World Health Organization W (1990) International classification of diseases (draft version: Diagnostic criteria for research). WHO, Geneva

111. Wozniak J, Biederman J, Faraone SV, Frazier J, Kim J, Millstein R, Gershon J, Thornell A, Cha K, Snyder JB (1997) Mania in children with pervasive developmental disorders revisited. J Am Acad Child Adolesc Psychiatry 36:1552-1560
112. Ylisaukko-oja T, Wendt T-v, Kempas E, Sarenius S, Varilo T, von Wendt L, Peltonen L, Jarvela I (2004) Genomewide scan for loci of Asperger syndrome. Mol Psychiatry 9:161-168

113. Ziatas K, Durkin K, Pratt C (2003) Differences in assertive speech acts produced by children with autism, Asperger syndrome, specific language impairment, and normal development. Dev Psychopathol 15:73-94 